(C) О.Ю. Усенко, М.О. Артеменко, О.П. Дмитренко, А.С. Ахмаді, 2020

УДК 616.14.018-089:[615.849.19]

\title{
Сучасні підходи до тактики та стратегії лікування варикотромбофлебіту підшкір- них вен нижніх кінцівок
}

\author{
О.Ю. Усенко, М.О. Артеменко, О.П. Дмитренко, А.С. Ахмаді
}

Наџіональний інститут хірургї та трансплантологї̈ ім. О.О. Шалімова НАМН Украӥни, Київ

\section{Реферат}

Вступ. Ендовенозні методики за останні роки фактично витісняють класичну хірургію варикозної хвороби. Але досі багатьма спеціалістами вважається, що їх застосування обгрунтоване лише при неускладнених формах варикозної хвороби, а наявність варикотромбофлебіту вимагає екстреного відкритого хірургічного втручання.

Мета дослідження: показати можливості та тактику застосування сучасних ендовенозних методик при варикозній хворобі, ускладненій варикотромбофлебітом, з урахуванням сучасних світових тенденцій.

Матеріали та методи. Із пацієнтів, котрі 2016-2019 рр. пройшли лікування із варикотромбофлебітом, було відібрано 3 групи по 15 пацієнтів, одна 3 яких включала пацієнтів, пролікованих ендовенозною лазерною коагуляцією, друга - радіочастотною облітерацією, третя група - пацієнти, проліковані консервативно. Дві перші групи отримували післяопераційну тромбопрофілактику прямими антикоагулянтами.

Результати досліджень та їх обговорення. Застосування ендовенозних методик при варикотромбофлебіті ефективно та безпечно, але при локалізованих формах консервативне лікування є достатньо ефективним. Варикотромбофлебіт $є$ показанням для застосування ендовенозних методик, якщо показане хірургічне лікування, окрім ситуацій 3 розташуванням тромбу власне в ділянці співусть.

Ключові слова: варикотромбофлебіт, радіочастотна облітерація, ендовенозна лазерна коагуляція вен.

Modern approaches to tactics and strategy of treatment of thrombophlebitis of the subcutaneous veins of the lower extremities

Usenko O. Yu., Artemenko M.O., Dmytrenko O.P., Akhmadi A.S.

National Institute for Surgery and Transplantology named after O.O. Shalimov NAMS of Ukraine

Abstract
Rationale. Endovenous techniques in recent years have actually superseded classic varicose veins surgery. But so far many experts believe that their use is justified only in uncomplicated forms of varicose veins, and the presence of varicotrombophlebitis requires emergency open surgery. The study aimed to show the possibilities and tactics of using modern endovenous techniques in varicose disease complicated by varicotrombophlebitis, taking into account current world trends.

Methods. 3 groups of 15 patients were selected from patients who underwent varicotrombophlebitis treatment in 20162019, one of which included patients treated with endovascular laser coagulation, the second group - radiofrequency obliteration, and the third group - patients were treated conservatively. The first two groups received postoperative thromboprophylaxis with direct anticoagulants.

Results. The use of endovenous techniques in varicotrombophlebitis is effective and safe, but with localized forms conservative treatment is quite effective. Varicotrombophlebitis is an indication for the use of endovenous techniques if surgical treatment is indicated, except for situations with the placement of a blood clot in the area of junctions.

Key words: varicotrombophlebitis, radiofrequency obliteration, endovenous laser vein coagulation.

Вступ. Варикотромбофлебіт (ВТФ, superficial venous thrombosis) - це запальний процес у варикозно змінених венах нижніх кінцівок, асоційований із тромбозом вказаних вен; термін тромбофлебіт використовується для визначення того ж самого процесу, але в незмінених варикозно венах [1]. У зарубіжній літературі частіше трапляється термін - тромбоз поверхневих вен [1]. Частота даного захворювання є більшою за тромбоз глибоких вен (ТГВ) та у США складає не менше 1 випадку на 1000 населення, досягаючи 125 тис випадків на рік [1]. Вік не $є$ визначальним фактором ризику, на відміну від статі: жінки страждають частіше за чоловіків (50-70\%) [2,3]. Фактори ризику ВТФ такі самі, як і для будь-якого тромботичного процесу: вагітність, хірургічні втручання, довгі подорожі, травми, онкологія та терапія естрогенами [4]. Від 4 до
$59 \%$ пацієнтів із варикозною хворобою (BХ) страждають на ВТФ [3,5]; також ВТФ є одним 3 основних факторів ризику ТГВ, який, у свою чергу, теоретично може призводити до розвитку тромбоемболії легеневої артерії (ТЕЛА) [5,6,7] Але, на даний момент, немає переконливих даних про прямий взаємозв'язок ВТФ (навіть в ділянці співусть) та ТЕЛА [8], навпаки дослідження [9] показали, що наявність ВТФ у межах 3 см від співустя вени достовірно не підвищує ризик ТЕЛА.

Враховуючи всі ці дані, згідно сучасними світовими консенсусами ВТФ з ураженням вен нижче коліна лікується консервативно, часто навіть без антикоагулянтів, ВТФ на рівні вище коліна є причиною для призначення антикоагулянтів або розгляду питання про оперативне лікування [2]. Ендовенозні методики, такі як ендовенозна лазерна 
коагуляція (ЕВЛК) та радіочастотна облітерація (РЧО), згідно з світовими консенсусами, є ефективними методиками лікування ВХ [10], але ВТФ може вважатися протипоказом для їх застосування [11].

Мета дослідження. Метою дослідження було оцінити доцільність хірургічного лікування та показати ефективність застосування ендовенозних методик в лікування ВТФ.

Матеріали та методи. За період із листопада 2015 по листопад 2019 рр. із пацієнтів з ВТФ, що проходили лікування на базі кабінету лазерної хірургії НІХТ ім. О.О. Шалімова було відібрано 3 групи по 15 пацієнтів із ВТФ.
У першій групі пацієнтів проводилась ЕВЛК ураженої вени 3 наступною мініфлебектомією притоків за Varady. В другій групі проводилась РЧО ураженої вени 3 наступною мініфлебектомією притоків за Varady. 3 метою отримання співставних результатів та зниження впливу аспектів хірургічної техніки всі втручання в обох групах проводились одним хірургом. У третій групі проводилось консервативне лікування ВТФ.

Розподіл пацієнтів у групах за статтю представлений в таблиці 1. Середній вік пацієнтів у групі

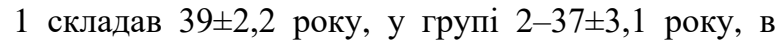
групі $3-36 \pm 3,2$.

Таблиця 1

Розподіл пацієнтів у групах за статтю

\begin{tabular}{|l|c|c|c|}
\hline Стать & 1 група & 2 група & 3 група \\
\hline Чоловіча стать & $5(33,33 \%)$ & $6(40 \%)$ & $7(46,67 \%)$ \\
\hline Жіноча стать & $10(66,67 \%)$ & $9(60 \%)$ & $8(53,33 \%)$ \\
\hline
\end{tabular}

Розподіл пацієнтів у групах за класифікацією СЕАР (1994) [12] та за типом будови вен [13] представлений у таблицях 2 та 3.

Таблиця 2

Розподіл пацієнтів у групах за класифікацією СЕАР

\begin{tabular}{|l|c|c|c|}
\hline С клас & 1 група & 2 група & 3 група \\
\hline C1 & - & - & \\
\hline C2 & $7(46,67 \%)$ & $6(40 \%)$ & $7(46,67 \%)$ \\
\hline C3 & $4(26,67 \%)$ & $4(26,67 \%)$ & $5(33,33 \%)$ \\
\hline C4 & $3(20 \%)$ & $4(26,67 \%)$ & $3(20 \%)$ \\
\hline C5 & $1(6,67 \%)$ & $1(6,67 \%)$ & \\
\hline C6 & - & - & \\
\hline
\end{tabular}

Розподіл пацієнтів у групах за типом будови вен

Таблиця 3

\begin{tabular}{|l|c|c|c|}
\hline \multicolumn{1}{|c|}{ Тип будови } & 1 група & 2 група & 3 група \\
\hline ВПВ і-типу & $6(40 \%)$ & $5(33,33 \%)$ & $5(33,33 \%)$ \\
\hline ВПВ h-типу & $4(26,67 \%)$ & $3(20 \%)$ & $5(33,33 \%)$ \\
\hline ВПВ s-типу & $3(20 \%)$ & $5(33,33 \%)$ & $3(20 \%)$ \\
\hline МПВ & $2(13,33 \%)$ & $2(13,33 \%)$ & $2(13,33 \%)$ \\
\hline
\end{tabular}

Перед лікуванням пацієнти всіх груп проходили загальноклінічне обстеження, яке включало, в тому числі, дослідження згортальної системи (коагулограма, д-димер тощо). Найважливіші показни- ки вказані в таблиці 4. Пацієнти 3 доведеними тромбофілічними станами або 3 обгрунтованою підозрою на них до дослідження не включались.

Таблиця 4

Показники згортальної системи крові

\begin{tabular}{|l|c|c|c|}
\hline \multicolumn{1}{|c|}{ Показник } & 1 група & 2 група & 3 група \\
\hline МНВ & $0,96 \pm 0,12$ & $0,94 \pm 0,14$ & $0,92 \pm 0,12$ \\
\hline Фібриноген, г/л & $4,1 \pm 0,5$ & $4,05 \pm 0,7$ & $4,0 \pm 1,0$ \\
\hline Д-димер, нгФЕО/мл & $890 \pm 115$ & $970 \pm 120$ & $850 \pm 140$ \\
\hline
\end{tabular}

Усі оперативні втручання у обох групах пацієнтів виконувались під місцевим знеболенням за

принципом стаціонару 1 дня. Ефективність проведеного втручання та контроль за ефективністю 
консервативного лікування оцінювалася за даними ультразвукової діагностики (УЗД) вен нижніх кінцівок, що проводились апаратом UGEOHM70A («Samsung», Південна Корея) на 2, 10, 30 день та через 3, 6 та 12 місяців, згідно з міжнародними рекомендаціями [10]. Усі УЗДобстеження проводились в ортостатичному положенні.

Мініфлебектомія притоків виконувалась за відомою методикою:

1. Тромбовані та не нетромбовані притоки вени видалялись за допомогою мініфлебектомії за технікою Varady [12].

ЕВЛК проводилась з використанням лазерного апарату «Ліка-Хірург» («Фотоніка Плюс», Україна) 3 довжиною хвилі 1470 нм та радіального світловоду 2Ring Radial («Biolitec», Німеччина) також згідно зі стандартною методикою [11]:

1. Під контролем УЗД пунктувалась за Seldinger уражена вена та світловод вводився до рівня 20 мм до СФС або СПС

2. Проводилась тумесцентна анестезія розчином Klein за допомогою інфільтраційної помпи під контролем УЗД з наступним проведенням коагуляції вени на потужності 10 Вт, з безперервною тракцією світловода зі швидкістю $0,7 \mathrm{~mm} / \mathrm{c}$.

3. Тромбовані та анетромбовані притоки вени видалялись за допомогою мініфлебектомії за технікою Varady [12].

РЧО проводилась із використанням радіочастотного апарату «RFG 2» («Medtronic», США) та електроду ClosureFast 3 робочою зоною 7 cм («Medtronic», США) також згідно зі стандартною методикою [13]:

1. Під контролем УЗД пунктувалась за Seldinger уражена вена та електрод вводився до рівня 20 мм до СФС або СПС.

2. Проводилась тумесцентна анестезія розчином Klein за допомогою інфільтраційної помпи під контролем УЗД з наступним проведенням радіочастотної коагуляції вени, в приустьовому відділі ВПВ в 3 проходи, в приустьовому відділу МПВ в 2 проходи, стовбури в 1 прохід.

3. Тромбовані та нетромбовані притоки вени видалялись за допомогою мініфлебектомії за технікою Varady [12].

Перші 2 групи пацієнтів у післяопераційному періоді упродовж 1 місяця носили компресійний трикотаж 2 класу компресії, в 3 групі компресійний трикотаж 2 класу компресії використовувався до 3 місяців.

Показання до застосування ЕВЛК чи РЧО виставлялися за результатами передопераційного УЗД вен нижніх кінцівок. ВТФ у басейні великої підшкірної вени (ВПВ) або малої підшкірної вени (МПВ) 3 розташуванням тромбу в ділянці сафено-феморального співустя (СФС) або сафено-поплітеального співустя (СПС), та/або провисання тромбу до глибокої венозної системи та/або відстань між проксимальним кінцем тромбу та СФС (або СПС) менше 5 см вважались абсолютними протипоказами для застосування ЕВЛК (рис. 1, 2, 3).

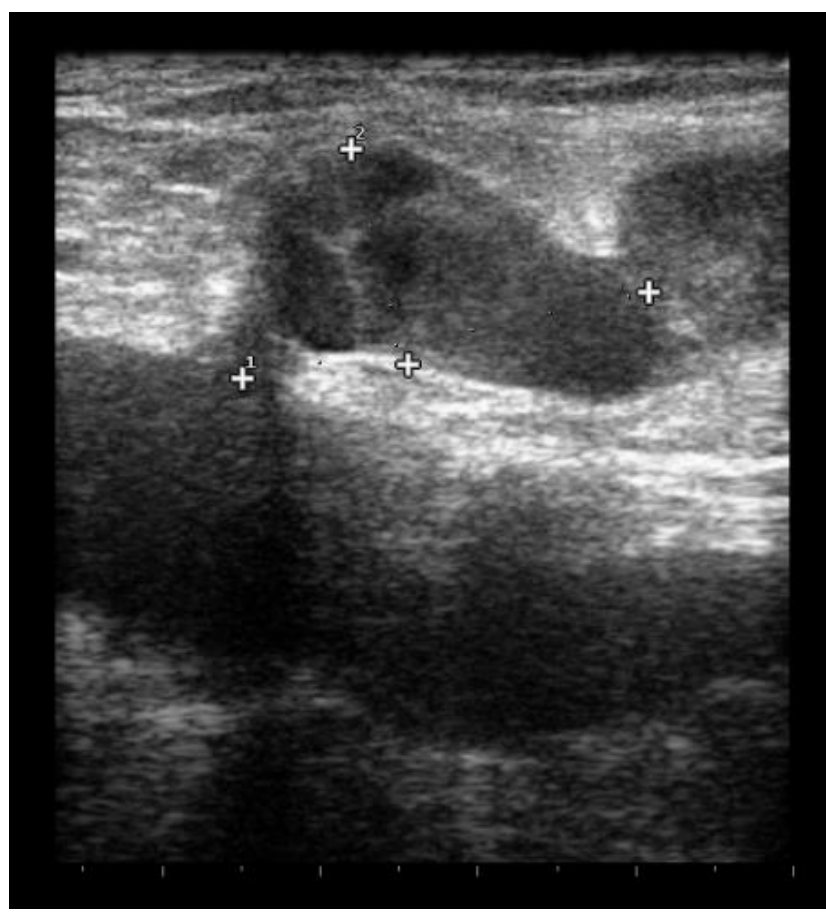

Рис. 1. Тромб у ВПВ від рівня СФС - проведення ЕВЛК технічно неможливе. 


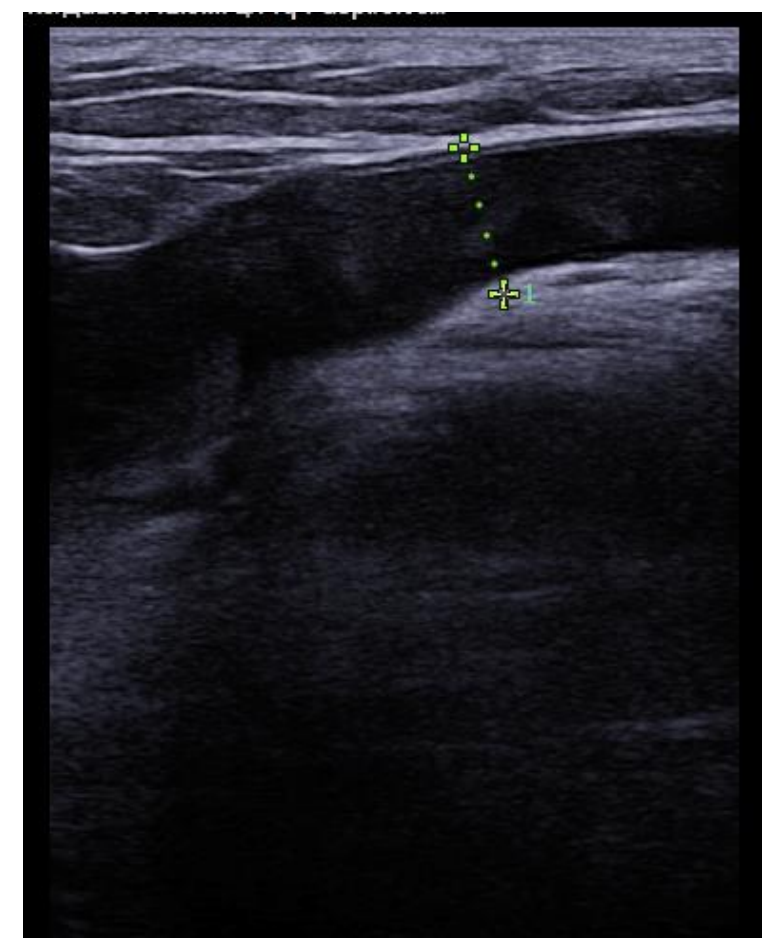

Рис. 2. Стовбур ВПВ прохідний - проведення ЕВЛК можливе, незважаючи на тромбовані притоки (рис. 3).

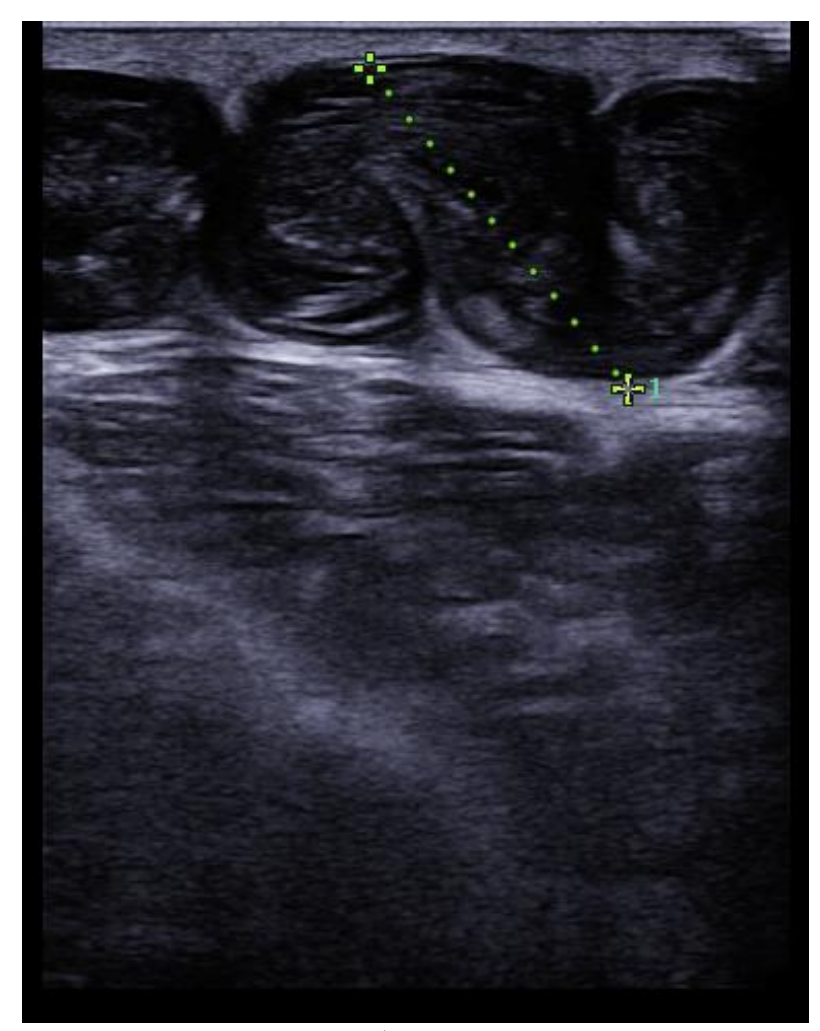

Рис. 3. Тромб у притоках ВПВ.

Усі пацієнти перших 2 груп у післяопераційному періоді 10 днів отримували антикоагулянтну терапію надропарином в дозі 0,3 в день операції, в дозі 0,6-5 днів після операції та в дозі 0,3 ще 4 дні після операції. Оцінка вираженості клінічної симптоматики та якості життя пацієнтів проводилась за шкалою VCSS (rev. 2010) [14] перед оператив- ним втручанням та на 7 та 30 добу післяопераційного періоду.

Пацієнти 3 ВТФ включались у 3 групу при умові відповідності критеріям для хірургічного лікування, але при небажанні пацієнта проводити хірургічне лікування. Згідно з даними УЗД пацієнти були розділені на 3 підгрупи [15]: 
1. Із низьким ризиком переходу на глибокі вени (ізольований ВТФ притоків ВПВ чи МПВ) 8 пацієнтів $(53,33 \%)$.

2. Із помірним ризиком переходу на глибокі вени (ВТФ магістральної підшкірної вени проксимальніше 3 см від співустя) - 6 пацієнтів $(40 \%)$.

3. Із високим ризиком переходу на глибокі вени (ВТФ магістральної підшкірної вени 3 см або дистальніше від співустя) - 1 пацієнт (6,67\%).

Пацієнти в усіх підгрупах використовували нестероїдні протизапальні засоби (мелоксикам 7,5 мг), топічні протизапальні засоби (гелі з нестероїдними протизапальними засобами та на основі гепаріну). 2 підгрупа отримувала додатково надропарин підшкірно 0,3 до 45 днів, 3 підгрупа отримувала надропарин підшкірно в дозі 0,6 до 45 днів.

Результати досліджень та їх обговорення. У 12 (80\%) пацієнтів 1 групи та $13(86,67 \%)$ пацієнтів 2 групи вена була облітерована, у 3 (20\%) пацієнтів 1 групи та 2 пацієнтів $(13,33 \%)$ в строки до 3 місяців була виявлена часткова локальна прохідність стовбура вени, яка усувалась повторною склеротерапією під контролем УЗД; в обох групах у всіх пацієнтів реканалізації первинно та повтор- но облітерованої вени в строки спостереження до 12 місяців не було. При цьому у 12 (80\%) пацієнтів в 1 групі та $13(86,67 \%)$ пацієнтів в 2 групі через 612 місяців облітерована вена на УЗД зовсім не визначалась. У 1 групі у 3 (20\%) пацієнтів виявлено гіпестезії на стегні, в 2 групі у $1(6,67 \%)$ пацієнта була локальна шкірна гіпестезія на гомілці. Випадків ТГВ чи ТЕЛА та клінічно значущих кровотеч виявлено не було.

У 3 групі пацієнтів, згідно з даними УЗД, повна реканалізація тромбів на строк до 3 місяців наступила у 12 (80\%) пацієнтів, у 3 (20\%) пацієнтів реканалізація була неповна. При цьому у всіх пацієнтів з групи з низьким ризиком розповсюдження на глибокі вени та у 4 (67\%) паціснтів 3 помірним ризиком розповсюдження на глибокі вени реканалізація була повна, у 2 пацієнтів (33\%) 3 помірним ризиком та у єдиного пацієнта з високим ризиком повна реканалізація не наступила.

У групі пацієнтів, що їм проводилась ЕВЛК або РЧО, якість життя поліпшилась та вираженість клінічної симптоматики знизилась швидше, ніж у 3 групі, про що свідчать дані VCSS, але через 3 місяці наступило поліпшення рівня життя та вираженість клінічної симптоматики до комфортного для пацієнтів рівня.

Результати VCSS по групах пацієнтів

Таблиця 5

\begin{tabular}{|c|c|c|c|}
\hline \multirow{2}{*}{} & \multicolumn{3}{|c|}{ Середній показник VCSS, бали } \\
\cline { 2 - 4 } & 1 група & 2 група & 3 група \\
\hline Перед втручанням/лікуванням & 5,7 & 5,6 & 5,7 \\
\hline 7 доба & 2,8 & 2,3 & 2,8 \\
\hline 30 доба & 1,5 & 1,4 & 2,1 \\
\hline 45 доба & 1,2 & 1,3 & 1,7 \\
\hline 90 доба & 1,2 & 1,2 & \\
\hline
\end{tabular}

Висновки. 1. Застосування ендовенозних методик при ВТФ ефективно та безпечно. Дані за 12 місяців спостереження показують високий рівень ефективності при вищій якості життя в післяопераційному періоді, ніж у пацієнтів після консервативного лікування.

2. Застосування антикоагулянтів у післяопераційному періоді дозволило ефективно запобігти тромботичним ускладненням в усіх групах пацієнтів. Питання застосування ендовенозних методик при ВТФ у пацієнтів $з$ тромбофілічними станами потребує подальшого вивчення.

3. ВТФ є показанням для застосування ендовенозних методик у тих же випадках, коли показана й флебектомія, окрім ситуацій з розташуванням тромбу власне в СФС (СПС) або ближче 5 см до них, що робить застосування таких методик технічно неможливим. Достовірної різниці в результатах при застосуванні ЕВЛК чи РЧО не виявлено, методики абсолютно рівнозначні.

4. Зважаючи на невелику кількість спостережень, питання використання ендовенозних методик у лікуванні ВТФ безперечно потребує подальшого дослідження, але безпосередні результати ï застосування в лікуванні ВТФ показали $100 \%$ ефективність закриття вени при відсутності ускладнень (в т.ч. тромботичних) при терміні спостереження до 12 місяців.

5. Форми ВТФ із низьким та помірним ризиком розповсюдження тромбів на глибокі вени піддаються ефективному консервативному лікуванню, при цьому значних ризиків тромботичних ускладнень не виявлено.

6. При формах ВТФ із високим ризиком розповсюдження тромбів на глибокі вени при неможливості консервативного лікування, хірургічне лікування є методом вибору.

Інформація про конфлікт інтересів. Автори заявляють про відсутність конфлікту інтересів при виконанні наукового дослідження та підготовці даної статті. 
Інформація про фінансування. Автори гарантують, що вони не отримували жодних винагород у будь-якій формі, здатних вплинути на результати роботи.

Особистий внесок кожного автора у виконання роботи:

Усенко О.Ю. - розробка концепції і дизайну дослідження, аналіз отриманих даних, редагування, статистична обробка даних.

Артеменко М.О. - збір матеріалу дослідження, розробка дизайну дослідження, аналіз отриманих даних.

Дмитренко О.П. - збір матеріалу дослідження, аналіз отриманих даних, підготовка тексту статті.

Ахмаді А.С.А.В. - збір матеріалу дослідження, аналіз отриманих даних.

\section{Список використаної літератури}

1. Gloviczki P, Dalsing MC, Eklöf B, Lurie F, Wakefield TW, Gloviczki ML. Handbook of Venous and Lymphatic Disorders: Guidelines of the American Venous Forum. CRC Press. 2016. https://doi.org/10.1201/9781315382449-2

2. Superficial thrombophlebitis (superficial venous thrombosis) / J. Scriven, H. Nasr// BMJ - $2015-$ Vol.350 P. $20-39$.

3. Recent finding sinthe epidemiology, diagnosis andt reatment of superficial-vein thrombosis. / H. Decousus,

L. Bertoletti, P. Frappe[etal.] //ThrombosisRes - 2011 - Vol.127(suppl 3) - P.81-85.

4. Superficial thrombophlebitis of the lower limb: practicalrecommendationsfordiagnosisandtreatment. / M.G.R. De Maeseneer // Acta Chir Belg. 2005. Vol.105. P. 145-147.

5. Clinical significance of superficial vein thrombosis. / L. Leon, A.D. Giannoukas, D. Dodd [et al.] // Eur J Vasc Endovasc Surg. 2005. Vol.29. P. 10-17.

6. Treatment for superficial thrombophlebitisoftheleg. /M. DiNisio, I.M. Wichers, S. Middeldorp // Cochrane Database Syst Rev. 2013. Vol.4:CD004982.

7. Progression of superficial venous thrombosis to deep vein thrombosis. /D.L. Chengelis, P.J.Bendick, J.L.Glover [et al.]// J VascSurg. 1996. Vol.24. P. 745-749.

8. Leizorovicz A, Becker F, Buchmüller A, Quéré I, Prandoni, P. Decousus H. Clinical relevance of symptomatic superficial-vein thrombosis extension: lessons from the CALISTO study. Blood.2013;122(10):1724-1729. https://doi.org/10.1182/blood-2013-0 4-498014

9. Гаврилов С.Г., Золотухин И.А., Пустовойт А.А. Приустьевая перевязка магистральнойподкожной вены по поводу острого восходящего тромбофлебита: гарантия от легочной эмболии? Флебология. 2011; 5(4):88-90.

10. The care of patients with varicose veins and associated chronic venous diseases: Clinical practice guidelines of the Society for Vascular Surgery and the American Venous Forum / P. Gloviczki, A.J. Comerota, M.C. Dalsing [et al.] // J VascSurg. 2011. Vol. 53. P. 2-48.

11. Guidelines of the First International Consensus Conference on Endovenous Thermal Ablationfor Varicose Vein Disease. ETAV ConsensusMeeting 2012 / M.D. Pavlovic, S. Schuller-Petrovic, O. Pichot[etal.] // Phlebology. 2014. doi: 10.1177/0268355514524568.

12. Revision of the CEAP classification for chronic venous disorders: Consensus statement / B. Eklof, R.B. Rutherford, J.J. Bergan [et al.] // J VascSurg. 2004. Vol. 40. P. 1248-1252.

13. Duplexultrasoundinvestigationoftheveinsinchronicvenousdiseaseofthelowerlimbs - UIP ConsensusDocument. Part II: Anatomy/A. Cavezzi, N. Labropoulos, H. Partsch[etal.] // Eur J VascEndovascSurg. 2006. Vol. 31. P. 288-299.

14. European guidelines for sclerotherapy in chronic venous disorders / E. Rabe, F. Pannier// Phlebology. 2014. Vol. 29(6). P. 338-354.

15. Diagnostic and minisurgical treatment of chronic venous insufficiency / Z. Varady, Z. Boehm // Erbetegsegek - 2006 - Vol 13 - Suppl. 1 - P. 51-53.

16. Radiofrequency ablation of varicose veins: Best practice techniques and evidence / S J Goodyear, I K NyamekyePhlebology 2015, Vol. 30(2S) 9-17

17.Revision of the venous clinical severity score: Venous outcomes consensus statement: Special communication of the American Venous Forum Ad Hoc Outcomes Working Group / M.A. Vasquez, E. Rabe, R.B. McLafferty [et al.] // J Vasc Surg. 2010. Vol.52. P.1387-1396.

18. Bourgoin-Jallieu F. Management of superficial vein thrombosis of the lower limbs: update and current recommendations. Phlebolymphology. 2015;22(2): 82-89.

Стаття надійшла до редакції: 14.02.2020 р. 